\title{
Implementation of Behavioristic Learning Theory in the Online Learning Process at SMP PGRI Gandoang Class VII
}

\author{
M. Givi Efgivia ${ }^{*}$, Cucu Ardiansyah ${ }^{2}$, Taufik Rusmayana ${ }^{3}$, M. Zuhdi ${ }^{4}$ \\ 1,2,3,4 Postgraduate Educational Technology, University of Ibnu Khaldun Bogor Indonesia \\ *Corresponding author email: mgivi@uika-bogor.ac.id
}

\begin{abstract}
Currently the learning process requires educators to be more creative in the learning process, and requires every educator to use a cooperative learning theory, and which can be implemented in online learning, so that it is no longer an ongoing problem just to deliver learning materials at SMP PGRI Gandoang. By trying to apply several learning theories, one of which uses Behavioristic learning theory in which Behavioristic learning theory is a learning theory that prioritizes changes in student behavior as a result of stimulus and response. In other words, learning is a form of change experienced by students in terms of their abilities that aim to change behavior by way of interaction between stimulus and response. According to Watson, student behavior is the result of genetic inheritance and environmental influences, while according to Pavlov it refers to a number of training procedures between one stimulus and a stimulus that appears to replace another stimulus in developing a response, the last according to Skinner, the relationship between stimulus and response occurs because through interaction with the environment. which then leads to changes in behavior. Thus, behavioristic learning theory focuses more on developing student behavior in a better direction.
\end{abstract}

Keywords: Learning Theory, Behavioristic, Learning

\section{INTRODUCTION}

In a pandemic condition like this, many learning processes cannot be carried out as before, where the learning process can be carried out face-to-face and it is easier to understand the condition of children in the learning process. Mid-March 2020, in Indonesia there were positive cases of Covid-19 (Corona Viruses) found Disease 19) with an increasing number of cases. One of the causes of the spread of Covid-19 is direct physical contact between humans. This underlies the policy of the Government of the Republic of Indonesia regarding learning activities carried out remotely (on the network) through a Circular from the Ministry of Education and Culture regarding the implementation of education policies in the emergency period of the spread of Covid-19 in 2020. Based on this policy learning in schools during the Covid-19 pandemic. 19 can be implemented in the network (online). so with the current state of the covid-19 pandemic, SMP PGRI Gandoang uses various learning theories, one of which is Behavioristic theory.

The use of learning theory with correct development steps and choice of subject matter as well as the use of good message design elements can make it easier for students to understand what is being learned. In addition, the learning atmosphere will feel more relaxed and fun. The learning process is essentially an invisible mental activity. That is, the process of change that occurs in a person who is learning cannot be seen clearly, but can be seen from the symptoms of behavioral changes. Online learning organized by schools must begin to adapt quickly by students and educators. Schools as a place for education for students should be able to facilitate devices to support the learning process that facilitates the learning process properly.

Based on the explanation above, a special study is needed that discusses the online learning process that has been carried out at SMP PGRI Gandoang. So that it can be used as a reference for educators, especially for junior high school education.

\section{METHOD}

This study uses a qualitative method of library research that seeks to examine various literatures and related scientific sources. In the context of developing the design of cognitivism education, on the contrary, the purpose of compiling this post is to describe the ASSURE educational model as an 
innovative instructional education model and focuses on the use of media in education and has a philosophical approach to cognitivism theory.

\section{RESULT AND DISCUSSION}

Behavioristic learning theory is a theory that studies human behavior. According to Desmita (2009:44) behavioristic learning theory is a theory of learning to understand human behavior that uses an objective, mechanistic, and materialistic approach, so that changes in behavior in a person can be done through conditioning efforts. In other words, studying a person's behavior should be done through testing and observing visible behavior, not by observing the activities of the internal body parts. This theory prioritizes observation, because observation is an important thing to see whether or not changes in behavior occur.

Learning is the result of the interaction between stimulus and response (Slavin, 2000). A person is considered to have learned if he can show changes in his behavior. According to this theory, the important nature of learning is input in the form of a stimulus and output in the form of a response. Stimulus is something that is given by educators to students, while the response is a reaction or student response to the stimulus provided by the educator. The process that occurs between the stimulus and response is not important to note because it cannot be observed and cannot be measured. What can be observed is the stimulus and response, therefore, what is given by educators (stimulus) and what is received by students (response) must be observable and measurable (Putrayasa, 2013).

\subsection{Characteristics of Behavioristic Learning Theory}

\subsubsection{John B. Watson}

According to Desmita (2009:44), behaviorism is a school in understanding human behavior which was developed by John B. Watson (1878-1958), an American psychologist in 1930 , as a reaction to psychodynamic theory. The behavioristic perspective focuses on the role of learning and explaining human behavior.

According to Watson (Putrayasa, 2013), learning as a process of interaction between stimulus and response, the stimulus and response in question must be observable and measurable. Therefore, a person recognizes mental changes in himself during the learning process. Someone considers these factors as things that do not need to be taken into account because they cannot be observed. Watson is a pure behaviorist, his study of learning is paralleled with other sciences such as physics or biology which is very oriented to purely empirical experience, that is, as far as it can be observed and measured. Watson assumes that only in this way can the changes that occur after a person perform an act of learning (Kunaefy, 2019).

\subsubsection{Ivan P. Pavlov}

The classical conditioning paradigm is the great work of Ivan P. Pavlov (1849-1936), a Russian scientist who developed a behavioral theory through experiments on dogs and their saliva. The process discovered by Pavlov, because the original and neutral stimulus or stimulus is usually repeatedly paired with reinforcing elements that cause a reaction. Neutral stimuli are called conditional or conditioned stimuli, which are abbreviated as CS (conditioned stimulus). The reinforcer is an unconditional stimulus or US (unconditioned stimulus). The natural reaction or the unlearned reaction is called the conditional reaction or $\mathrm{CR}$ conditioned response). Pavlov applied these terms as a force. He meant that every agent is like food, which reduces a part of a need. Thus the dog's mouth will salivate (UR) in reaction to food (US). If a neutral stimulus, such as a bell or clapper (CS) is sounded at the same time as the presentation time, this event will cause salivation (CR) (Desmita, 2005:55).

Through his classical conditioning paradigm, Pavlov showed that dogs can be trained to salivate not on initial stimuli (food), but on sound stimuli. This occurs when showing food to the dog as a stimulus that causes salivation, followed by ringing the bell or the bell repeatedly, eventually the dog will salivate when he hears the sound of the bell or bell, even though food is not shown or given. Here it is seen that food stimuli have shifted to sound stimuli to show the same answer, namely salivation. This classical conditioning paradigm becomes a paradigm of various behavior formation which is a series from one to another. This classic condition is also related to the involuntary nervous system and its muscles. Thus, emotional is something that is formed through classical conditioning (Desmita, 2005:56)

Classical conditioning learning theory refers to a number of training procedures because one stimulus and stimulus appear to replace another stimulus in developing a response. This procedure is called classical because of its historical priority as developed by Pavlov. The classic word that begins the name of this theory is used solely to appreciate Pavlov's work which is considered the earliest in the field of conditioning (conditioning efforts) and to distinguish it from other conditioning theories. The feeling of learning people is passive because to make a response it is necessary to have a certain stimulus, while regarding reinforcement according to Pavlov, an uncontrolled stimulus (unconditioned stimulus) has 
a relationship with reinforcement. The stimulus causes repetition of behavior and serves as a reinforcement (Zulhammi, 2015).

\subsubsection{B.F. Skinner}

Skinner is a psychologist from Harvard who has been credited with developing Watson's theory of behavior. His view of personality is called radical behaviorism. Behaviorism emphasizes the scientific study of observable behavioral responses and environmental determinants. In Skinner's behaviorism, thought, consciously or unconsciously, is not needed to explain behavior and development. According to Skinner, development is behavior. Therefore, behaviorists believe that development is learned and often changes according to environmental experiences. To demonstrate operant conditioning in the laboratory, Skinner placed a hungry mouse in a box, which he called the Skinner box. In the box, mice are allowed to do activities, walk and explore their surroundings. In this activity, the rat accidentally touched a lever and caused food to come out. Mice do the same activity again to get food, namely by pressing the lever. The longer it goes on the less activity is done to touch the lever and get food. Here rats study the relationship between levers and food. This relationship will be formed if food remains a reward for the activities carried out by rats (Kunaefy, 2019).

Operant conditioning also involves learning processes using conscious muscles that elicit a response followed by repetition for reinforcement. But this is still influenced by the stimuli that exist in the environment, namely the condition and quality and the reinforcement of the stimuli affect the answers that will be shown. Therefore, reinforcement of the repetition of stimuli shown an answer to the expected behavior is important in operant conditioning. In order for a new answer or behavior to continue to be shown, it is necessary to strengthen secondary stimuli or through planned reinforcement of stimuli (Desmita, 2005: 58).

Skinner's concepts about learning outperform the concepts of the previous characters. Skinner explained the concept of learning in a simple, but more comprehensive way. According to Skinner, the relationship between stimulus and response that occurs through interaction with the environment, then causes changes in behavior that are not as simple as those stated by previous characters. According to him, the response that a person receives is not as simple as that, because the stimuli given will interact with each other and the interactions between these stimuli will affect the resulting response. This response has consequences. These consequences will affect the emergence of behavior (Slavin, 2000). Therefore, in understanding one's behavior one must understand the relationship between one stimulus and another, and understand the concepts that may arise and the various consequences that arise as a result of the response. Skinner also suggests using mental changes as a tool to explain behavior which only adds to the complexity of the problem, because every tool used needs an explanation (Putrayasa, 2013).

\subsection{Application of Behavioristic Learning Theory in the Learning Process}

Behavioristic learning theory emphasizes the formation of visible behavior as a result of learning. Behavioristic learning theory with a stimulus response relationship model emphasizes students who learn as passive individuals. The emergence of strong student behavior when given reinforcement and will disappear if subject to punishment (Nasution, 2006:66). Behavioristic learning theory has an effect on learning problems, because learning is interpreted as exercises for the formation of the relationship between stimulus and response. By providing stimuli, students will react and respond to these stimuli. Stimulus-response relationships give rise to automatic habits of learning. Thus the child's behavior consists of certain responses to certain stimuli.

The application of behavioristic theory in learning activities depends on several components such as: learning objectives, subject matter, student characteristics, media, learning facilities, environment, and reinforcement (Sugandi, 2007:35). Behavioristic learning theory tends to direct students to think. The view of behavioristic learning theory is a process of formation, which is to bring students to achieve certain targets, so that students are not free to be creative and imaginative. Learning designed in behavioristic learning theory views knowledge as objective, so that learning is the acquisition of knowledge, while teaching is transferring knowledge to students. Therefore, students are expected to have the same understanding of the knowledge being taught. That is, what is explained by the educator is what students must understand

The most important thing in behavioristic learning theory is the input and output in the form of a response. According to this theory, the stimulus and response are considered unimportant because they cannot be observed and measured. Thus, what can be observed is only the stimulus and response. Therefore, what is given by educators and what is produced by students must all be observable and measurable which aims to see changes in behavior. Another important factor in behavioristic learning theory is the reinforcement factor. Viewed from the definition of reinforcement 
is anything that can strengthen the emergence of a response. The behavioristic view is less able to explain the variations in students' emotional levels, even though students have the same experience of reinforcement. The behavioristic view cannot explain two children who have relatively safe abilities and experiences of reinforcement. Judging from their abilities, the two children have different behaviors and responses in understanding a lesson. Therefore, behavioristic learning theory only recognizes the existence of observable stimuli and responses.

Behavioristic learning theory does not pay attention to the influence of thoughts or feelings that bring together the observed elements (Putrayasa, 2013: 49) Behavioristic learning theory emphasizes changes in behavior as a result of the interaction between stimulus and response, while learning as an activity that requires students to reexpress knowledge already studied. According to Mukinan (1997:23), some of these principles are: (1) behavioristic learning theory assumes that what is called learning is a change in behavior. A person is said to have learned if the person concerned can show changes in behavior, (2) this theory assumes that the most important thing in learning is the presence of stimulus and response, because this can be observed, while what happens is considered unimportant because it cannot be observed, and (3) reinforcement, which is anything that can strengthen the emergence of a response, is an important factor in learning. Education seeks to develop student behavior in a better direction. Educators try to understand students who are growing up. The development of behavior is the object of observation of the schools of behaviorism. Behavior can be in the form of attitudes, speech, and actions of a person so that this behavior is part of psychology. Therefore, educational psychology examines problems that affect the behavior of people or groups in the learning process.

\section{SUMMARY}

Behavioristic learning theory is a learning theory that emphasizes human behavior as a result of the interaction between stimulus and response. Behavioristic learning theory influences the development of educational and learning theories known as behavioristic schools. The main focus in behavioristic learning theory is visible behavior and the external causes that stimulate it. Learning is a change in behavior as a result of experience. Learning based on behavior is obtained from environmental conditioning. This conditioning occurs through interaction with the environment. Behavioristic learning theory tends to direct students to think. The view of behavioristic learning theory is a process of formation, which is to bring students to achieve certain targets, thus making students who are not free to be creative and imaginative. Learning designed in behavioristic learning theory views knowledge as objective, so that learning is the acquisition of knowledge, while teaching is transferring knowledge to students.

\section{REFERENCES}

[1]. Irwan Nahar, N. (2016). Penerapan Teori Belajar Behavioristik dalam Proses Pembelajaran. Jurnal Ilmu Pengetahuan Sosia; L, 1. https://doi.org/10.1111/j.13652141.1992.tb08137.x

[2]. Istiadah, F. N. (2020). Teori-teori belajar dalam pendidikan. EDU PUBLISHER.

[3]. Kunaefy, M. A. (2019). Pandangan Behavioristik dan Penerapannya Dalam Pembelajaran. 1-16.

[4]. Putrayasa, I. B. (2013). Landasan Pembelajaran. Singaraja, Bali: UNDIKSHA Press. Tersedia Secara Online Di: Http://Pasca. Undiksha. Ac. Id/Media/1227. Pdf [Diakses Di Kota Malang, Indonesia: 2 Maret 2017].

[5]. Zulhammi, Z. (2015). Teori belajar behavioristik dan humanistik dalam perspektif pendidikan Islam. Darul'Ilmi: Jurnal Ilmu Kependidikan Dan Keislaman, 3(1), 105-125.

[6]. Zurni. (2020). Peningkatan Hasil Belajar Pada Pembelajaran Pkn Melalui Model Cooperative Learning Tipe Snowball Throwing Di Kelas V. Jurnal Manajemen Pendidikan, 05(1), 72.

[7]. Istiadah, F. N. (2020). Teori-teori belajar dalam pendidikan. EDU PUBLISHER.

[8]. Irwan Nahar, N. (2016). Penerapan Teori Belajar Behavioristik dalam Proses Pembelajaran. Jurnal Ilmu Pengetahuan Sosia; L, 1. https://doi.org/10.1111/j.13652141.1992.tb08137.x

[9]. Istiadah, F. N. (2020). Teori-teori belajar dalam pendidikan. EDU PUBLISHER.

[10]. Kunaefy, M. A. (2019). Pandangan Behavioristik dan Penerapannya Dalam Pembelajaran. 1-16.

[11]. Putrayasa, I. B. (2013). Landasan Pembelajaran. Singaraja, Bali: UNDIKSHA Press. Tersedia Secara Online Di: Http://Pasca. Undiksha. Ac. Id/Media/1227. Pdf [Diakses Di Kota Malang, Indonesia: 2 Maret 2017]. 
[12]. Zulhammi, Z. (2015). Teori belajar behavioristik dan humanistik dalam perspektif pendidikan Islam. Darul'Ilmi: Jurnal Ilmu Kependidikan Dan Keislaman, $3(1), 105-125$.

[13]. Zurni. (2020). Peningkatan Hasil Belajar Pada Pembelajaran Pkn Melalui Model
Cooperative Learning Tipe Snowball Throwing Di Kelas V. Jurnal Manajemen Pendidikan, 05(1), 72. 